\title{
Berberine regulates the microRNA-21-ITGB4-PDCD4 axis and inhibits colon cancer viability
}

\author{
YANFENG LÜ ${ }^{1}$, BINGBING HAN $^{2}$, HUALONG YU ${ }^{1}$, ZHENGHUA CUI $^{1}$, ZHIWEN LI $^{1}$ and JIANXIN WANG ${ }^{1}$ \\ ${ }^{1}$ Department of Anoproctology, The Second Hospital of Shandong University, Jinan, Shandong 250033; \\ ${ }^{2}$ Microcirculation Laboratory, Shandong University of Traditional Chinese Medicine, Jinan, Shandong 250014, P.R. China
}

Received November 26, 2015; Accepted May 16, 2017

DOI: $10.3892 / \mathrm{ol} .2018 .7997$

\begin{abstract}
Berberine is sourced from multiple medicinal herb resources and is easy to extract. With the advantages of low price, safety and convenience, berberine may have potential for wide clinical use. The present study aimed to investigate whether berberine inhibited the viability of colon cancer and whether it regulated the three-gene network microRNA (miR)-21-integrin $\beta 4$ (ITG $\beta 4$ )-programmed cell death 4 (PDCD4). It was demonstrated that berberine treatment suppressed colon cancer cell viability, and induced apoptosis and activated caspase- 3 activity in the human colon carcinoma HCT116 cell line. Berberine inhibited miR-21 expression and promoted ITG $\beta 4$ and PDCD4 protein expression in the HCT116 cell line. Overexpression of miR-21 reduced the anti-cancer effects of berberine on cell viability, apoptosis rate and caspase-3 activity of the HCT116 cell line. However, it was revealed that the overexpression of miR-21 also suppressed ITG $\beta 4$ and PDCD4 protein expression in the HCT116 cell line. In conclusion, miR-21, ITG $\beta 4$ and PDCD4 are involved in the anti-cancer effects of berberine on cell viability and apoptosis in the HCT116 cell line.
\end{abstract}

\section{Introduction}

Colon cancer is a type of malignant cancer with a high rate of incidence. Its morbidity is increasing and it is ranked third among malignant types of cancer in China, with an incidence rate of $12.81 \%$ in 2010 (1). At present, the morbidity of colon cancer is increasing due to the advancement of living standards and changes in dietary structure, including increased consumption of fatty components and decreased consumption of cellulose (2).

Correspondence to: Dr Jianxin Wang, Department of Anoproctology, The Second Hospital of Shandong University, 247 Beiyuan Street, Jinan, Shandong 250033, P.R. China

E-mail: jian_xinwang@yeah.net

Key words: berberine, colon cancer, microRNA-21, integrin $\beta 4$, programmed cell death 4
MicroRNA (miR/miRNA)-21 has previously been demonstrated to be upregulated in various types of tumors and to control the occurrence and progression of cancer (3). Tumors occur as a result of downregulation of cancer suppressor genes and overexpression of oncogenes (3). It has been demonstrated that miR-21 is a carcinogenic miRNA and it exhibits high expression levels in solid tumors, including head and neck neoplasms, esophageal, gastric, pancreatic, lung, liver, breast and prostatic cancer, and non-solid tumors including B cell lymphoma and chronic lymphocytic leukemia $(4,5)$.

The occurrence of colon cancer is a complex process involving multiple genes and multiple steps (6). The mutation and deficiency of tumor suppressor genes is one of the important factors resulting in cell malignancy and metastasis (7). Multiple studies have endeavored to define the use of expression profiles in determining the occurrence and progression of colon cancer $(7,8)$. In total, >200 miRNAs have been identified from 15 paired colon cancer and para-carcinoma tissues (9). Among the 132 miRNAs which are expressed in colorectal cancer (CRC) and para-carcinoma tissues, 47 of these have been revealed to be downregulated in colon cancer (10). A previous study has demonstrated that the upregulation of miR-21 is associated with CRC (10).

Studies on berberine (Fig. 1) have revealed that it is able to treat various infectious diseases, and that it is a potential anti-cancer treatment $(11,12)$. Berberine is a Chinese herb extract with a long history. Clinically, it is used to treat gastrointestinal diseases including enteritis and bacillary dysentery. In previous years, berberine has been revealed to possess therapeutic actions against multiple types of cancer, including osteosarcoma, prostatic and liver cancer (13-15). The present study sought to define whether berberine inhibited cell viability and induced apoptosis of the HCT116 colon cancer cell line via the regulation of miR-21-integrin $\beta 4$ (ITG $\beta 4$ )-programmed cell death 4 (PDCD4).

\section{Materials and methods}

Cell lines and cell culture. The human CRC HCT116 cell line was purchased from Shanghai cell bank (Shanghai, China) maintained in Dulbecco's Modified Eagle's medium (Gibco; Thermo Fisher Scientific, Inc., Waltham, MA, USA) supplemented with $10 \%$ fetal bovine serum (Hyclone; GE Healthcare Life Sciences, Logan, UT, USA), $100 \mathrm{mg} / \mathrm{ml}$ streptomycin 
Table I. Primers used for reverse transcription-quantitative polymerase chain reaction analysis.

\begin{tabular}{lll}
\hline Target & Primer & \multicolumn{1}{c}{ Sequence } \\
\hline miR-21 & Forward & 5'-GCGGCAACACCAGTCGATG-3' \\
& Reverse & 5'-TGCGTGTCGTGGAGTC-3' \\
U6 & Forward & 5'-GCTTCGGCAGCACATATACTAAAAT-3' \\
& Reverse & 5'-CGCTTCACGAATTTGCGTGTCAT-3' \\
\hline
\end{tabular}

miR, microRNA.

(Beyotime Institute of Biotechnology, Haimen, China) and $100 \mathrm{U} / \mathrm{ml}$ penicillin (Beyotime Institute of Biotechnology) at $37^{\circ} \mathrm{C}$ with $5 \% \mathrm{CO}_{2}$ in a humidified atmosphere.

Cellular viability assay. Human CRC HCT116 cells $\left(1 \times 10^{3}\right.$ cell/well) were seeded into 96 -well plates and cultivated with negative control (PBS), 1, 10 or $100 \mu \mathrm{M}$ berberine for $48 \mathrm{~h}$ at $37^{\circ} \mathrm{C}$. MTT was added to a final concentration of $0.5 \mathrm{mg} / \mathrm{ml} 48 \mathrm{~h}$ subsequent to berberine treatment and HCT116 cells were incubated for an additional $4 \mathrm{~h}$ at $37^{\circ} \mathrm{C}$. DMSO was then added into each well and incubated for a further $20 \mathrm{~min}$. The optical density was measured at $570 \mathrm{~nm}$ with a microplate spectrophotometer.

Apoptosis assay. HCT116 cells were plated in 6-well plates at a density of $5 \times 10^{5}$ cells/well and incubated with 1,10 and $100 \mu \mathrm{M}$ berberine for $24 \mathrm{~h}$ at $37^{\circ} \mathrm{C}$. Flow cytometry (C6; BD Biosciences, Franklin Lakes, NJ, USA) was used to measure the apoptosis of HCT116 cells, $24 \mathrm{~h}$ following treatment with berberine. The relative amount of Annexin V-fluorescein isothiocyanate-positive-propidium iodide-negative cells were detected using an Apoptosis Detection kit I (BD Biosciences) and analyzed using Flowjo 7.6.1 (BD Biosciences).

Caspase-3 activity. HCT116 cells were plated in 6-well plates at a density of $5 \times 10^{5}$ cells/well and incubated with 1,10 and $100 \mu \mathrm{M}$ berberine for $24 \mathrm{~h}$ at $37^{\circ} \mathrm{C}$. Proteins were extracted from HCT116 cells or HCT116 cells transfected by miR-21 using a protein extraction reagent (RIPA; Beyotime Institute of Biotechnology, Haimen, China). The supernatant was gathered after centrifugation at $12,000 \mathrm{xg}$ for $10 \mathrm{~min}$ at $4^{\circ} \mathrm{C}$ and the protein concentration was measured using a BCA Protein Assay kit (Beyotime Institute of Biotechnology). An equal amount $(50 \mu \mathrm{g})$ of total protein was incubated with Ac-IETD-pNA (Caspase-3 activity kit; cat. no. C1116; Beyotime Institute of Biotechnology) at $37^{\circ} \mathrm{C}$ for $4 \mathrm{~h}$. Caspase-3 activity was detected using a microplate spectrophotometer, at a wavelength of $405 \mathrm{~nm}$.

Reverse transcription-quantitative polymerase chain reaction (RT-qPCR). HCT116 cells were plated in 6-well plates at a density of $5 \times 10^{5}$ cells/well and incubated with 1,10 and $100 \mu \mathrm{M}$ berberine for $24 \mathrm{~h}$ at $37^{\circ} \mathrm{C}$. Total RNA was extracted from HCT116 cells cultured with berberine using TRIzol (Invitrogen; Thermo Fisher Scientific, Inc.), according to the manufacturer's protocol. RNA was then reverse transcribed into cDNA using a PrimeScript RT reagent kit (Takara Biotechnology Co., Ltd., Dalian, China). QPCR assay was

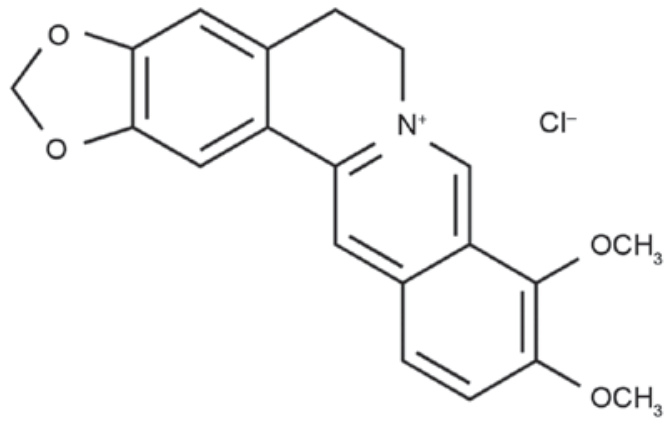

Figure 1. Chemical structure of berberine.

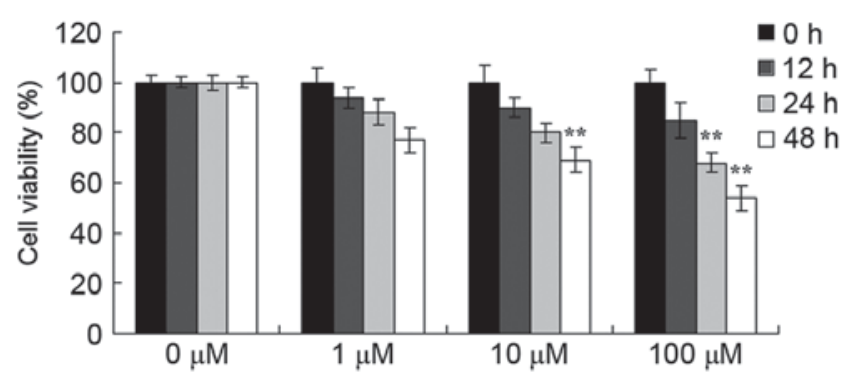

Figure 2. Berberine suppresses HCT116 cell viability. The treatment concentrations of berberine were $0,1,10$ and $100 \mu \mathrm{M}$. ${ }^{* *} \mathrm{P}<0.01$ vs. $0 \mu \mathrm{M}$ berberine treatment group.

performed on an Applied Biosystems ABI Prism 7000 sequence detection system using QuantiTect SYBR-Green PCR kit (Qiagen China Co., Ltd., Shanghai, China). The thermocycler conditions were as follows: $95^{\circ} \mathrm{C}$ for $5 \mathrm{~min}$, followed by 35 cycles of $95^{\circ} \mathrm{C}$ for $30 \mathrm{sec}, 58^{\circ} \mathrm{C}$ for $30 \mathrm{sec}$ and $72^{\circ} \mathrm{C}$ for $30 \mathrm{sec}$. The primers used for stem-loop RT-qPCR for miR-21 and U6 are presented in Table I. The relative expression levels of the gene of interest were quantified using the $2^{-\Delta \Delta \mathrm{Cq}}$ method, and U6 represented the internal control (16).

Cell transfection. miR-21 mimics and negative control mimics sequences were as follows: 5'-UAGCUUAUCAGACUG AUGUUGA-3' and 5'-CCCCCCCCCCCCCCCCCCCC-3', respectively. miR-21 mimics and negative control mimics were transfected into HCT116 cells using Lipofectamine 2000 (Invitrogen; Thermo Fisher Scientific, Inc.) according to the manufacturer's protocol.

Western blot analysis. HCT116 cells were plated in 6-well plates ( $5 \times 10^{5}$ cells/well) and incubated with 1,10 and $100 \mu \mathrm{M}$ berberine 

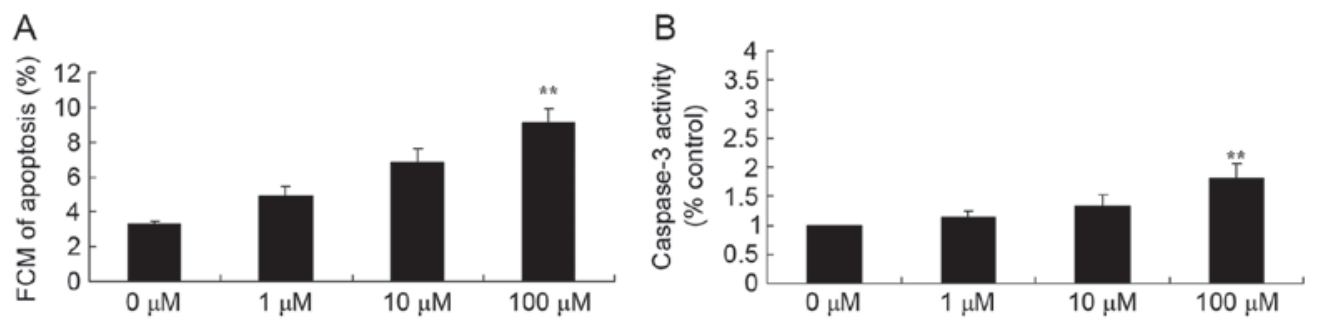

Figure 3. Berberine induces apoptosis and caspase-3 activity in HCT116 cells. Berberine induced (A) increased apoptosis and (B) increased caspase-3 activity in HCT116 cells. ${ }^{* *} \mathrm{P}<0.01$ vs. $0 \mu \mathrm{M}$ berberine treatment group. FCM, flow cytometry.

for $24 \mathrm{~h}$ at $37^{\circ} \mathrm{C}$. Proteins were extracted from HCT116 cells or HCT116 cells transfected with miR-21 using a protein extraction reagent (RIPA; Beyotime Institute of Biotechnology). The supernatant was gathered after centrifugation at $12,000 \times \mathrm{g}$ for $10 \mathrm{~min}$ at $4^{\circ} \mathrm{C}$ to measure protein concentration using a BCA Protein Assay kit (Beyotime Institute of Biotechnology). A total of $50 \mu \mathrm{g}$ protein per lane from each sample was separated using 10-12\% SDS-PAGE (Beyotime Institute of Biotechnology) and transferred onto a polyvinylidene difluoride membrane (Bio-Rad Laboratories, Inc., Hercules, CA, USA). The membrane was then blocked with $5 \%$ non-fat milk for $1 \mathrm{~h}$ at $37^{\circ} \mathrm{C}$ and incubated with ITG $\beta 4$ (dilution, 1:3,000; EPR8559; Abcam, Cambridge, UK), PDCD4 (dilution, 1:3,000; sc-376430; Santa Cruz Biotechnology, Inc.) and $\beta$-actin (dilution, 1:1,000; cat. no. sc-7210; Santa Cruz Biotechnology, Inc.) overnight at $4^{\circ} \mathrm{C}$. The membranes were incubated with horseradish peroxidase-labeled goat anti-rabbit or anti-mouse immunoglobulin G (dilution, 1:1,000; sc-2004, sc-2005; Santa Cruz Biotechnology, Inc.) for $1 \mathrm{~h}$ at room temperature, and membranes were developed using an enhanced chemiluminescence kit according to the manufacturer's protocol (Beyotime Institute of Biotechnology) and quantified using sodium Image_Lab_3.0 (Bio-Rad Laboratories, Inc.).

Statistical analysis. All statistical analyses were performed using SPSS 12.0 software (SPSS, Inc., Chicago, IL, USA). Data are presented as the mean \pm standard deviation. The differences between groups were analyzed using the Student's t-test. $\mathrm{P}<0.05$ was considered to indicate a statistically significant difference.

\section{Results}

Berberine suppresses the viability of HCT116 cells. The results of the MTT assay demonstrated the anti-cancer effects of berberine on HCT116 cell viability. Berberine reduced the viability of HCT116 cells in a time- and dose-dependent manner (Fig. 2). Notably, treatment with $10 \mu \mathrm{M}$ berberine significantly suppressed the cellular viability of HCT116 cells at $48 \mathrm{~h}$, and treatment with $100 \mu \mathrm{M}$ berberine also significantly suppressed the cellular viability of HCT116 cells at 24 or 48 h (Fig. 2).

Berberine induces apoptosis and caspase-3 activity of HCT116 cells. The results from flow cytometry analysis and the Business kit demonstrated that $100 \mu \mathrm{M}$ berberine treatment significantly increased the apoptosis rate and promoted caspase-3 activity of HCT116 cells, (Fig. 3A and B, respectively), and the effect of berberine was dose-dependent.

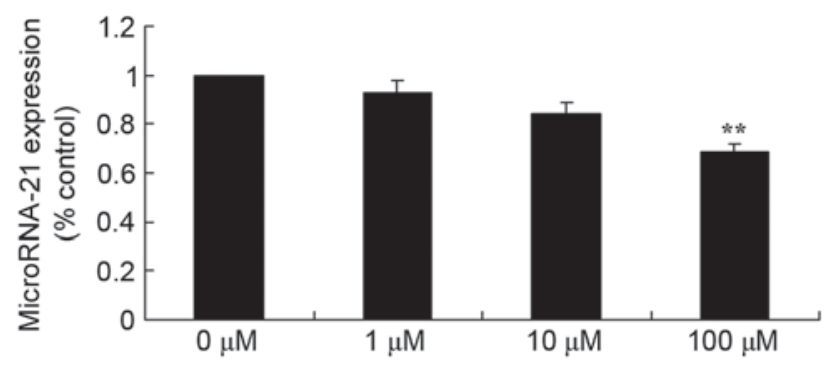

Figure 4. Berberine suppresses microRNA-21 expression in HCT116 cells. ${ }^{* *} \mathrm{P}<0.01$ vs. $0 \mu \mathrm{M}$ berberine treatment group.

Berberine suppresses miR-21 in HCT116 cells. In addition, the present study examined miR-21 expression in HCT116 cells treated with berberine using RT-qPCR. Compared with the $0 \mu \mathrm{M}$ control group, miR-21 expression was significantly inhibited by treatment with $100 \mu \mathrm{M}$ berberine (Fig. 4).

Berberine induces ITG $\beta 4$ protein expression in HCT116 cells. To explore the mechanisms underlying the effect of berberine on human colon cancer, ITG $\beta 4$ protein expression was detected using western blot analysis. ITG $\beta 4$ protein expression was significantly increased in HCT116 cells treated with $100 \mu \mathrm{M}$ berberine compared with the $0 \mu \mathrm{M}$ berberine group (Fig. 5).

Berberine induces PDCD4 protein expression in HCT116 cells. In order to detect the mechanisms by which berberine acts on human colon cancer, western blot analysis was used to analyze PDCD4 protein expression in HCT116 cell exposed to berberine. PDCD4 protein expression levels were significantly increased following treatment with $100 \mu \mathrm{M}$ berberine compared with the $0 \mu \mathrm{M}$ berberine group (Fig. 6).

Effect of miR-21 overexpression on the berberine-induced reduction of HCT116l cell viability. The present study analyzed the association between miR-21 and the anti-cancer effect of berberine on HCT116 cell viability. Transfection with miR-21 mimics significantly increased miR-21 expression levels in HCT116 cells (Fig. 7A) and that HCT116 cell viability was increased in cells treated with miR-21 mimics and $100 \mu \mathrm{M}$ berberine compared with the group treated with $100 \mu \mathrm{M}$ berberine only (Fig. 7B).

Effect of miR-21 overexpression on the effect of berberine on apoptosis and caspase-3 activity in HCT116 cells. To investigate the associations between miR-21 and the anti-cancer 

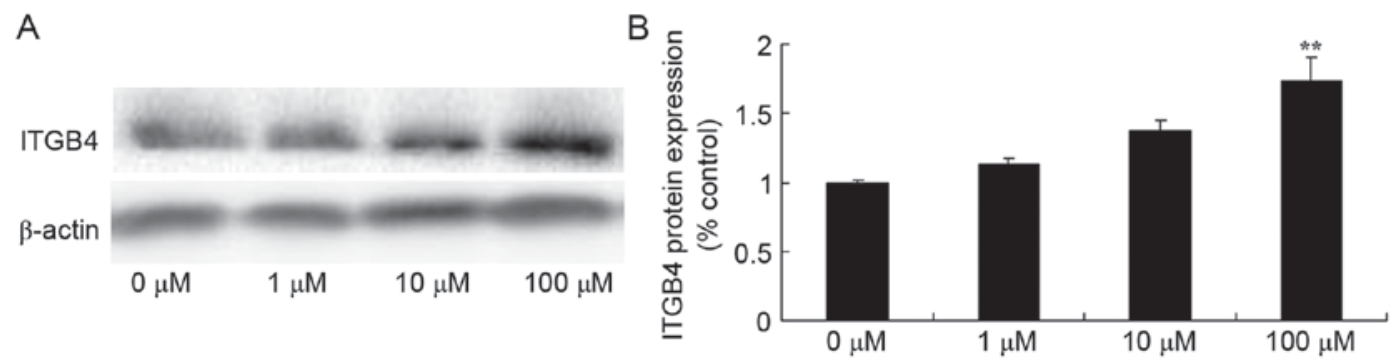

Figure 5. Berberine induces ITG $\beta 4$ protein expression in HCT116 cells. (A) Western blot analysis demonstrated that berberine induced ITG $\beta 4$ protein expression. (B) Quantification of the western blot analysis. ${ }^{* *} \mathrm{P}<0.01$ vs. $0 \mu \mathrm{M}$ berberine treatment group. ITG $\beta 4$, integrin $\beta 4$.

A

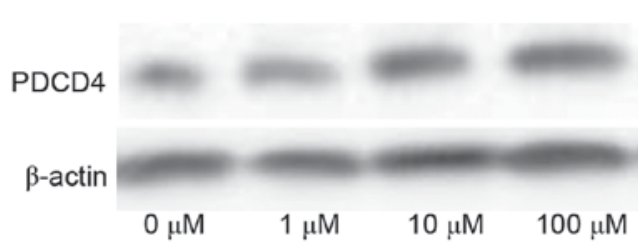

B

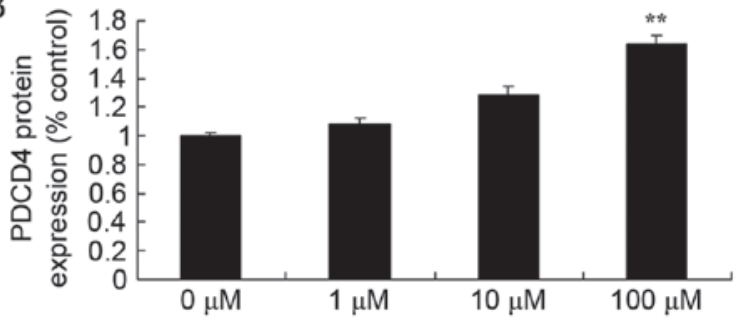

Figure 6. Berberine induces PDCD4 protein expression in HCT116 cells. (A) Western blot analysis demonstrated that PDCD4 protein expression increased with increasing concentrations of berberine. (B) Quantification of the western blot analysis. ${ }^{* *} \mathrm{P}<0.01$ vs. $0 \mu \mathrm{M}$ berberine treatment group. PDCD4, programmed cell death 4 .

A

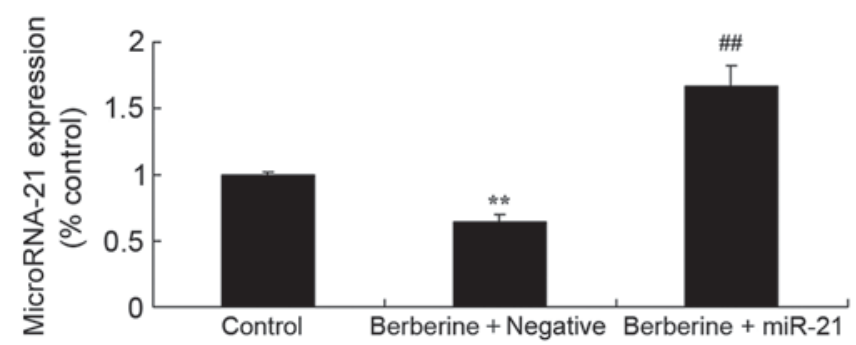

B

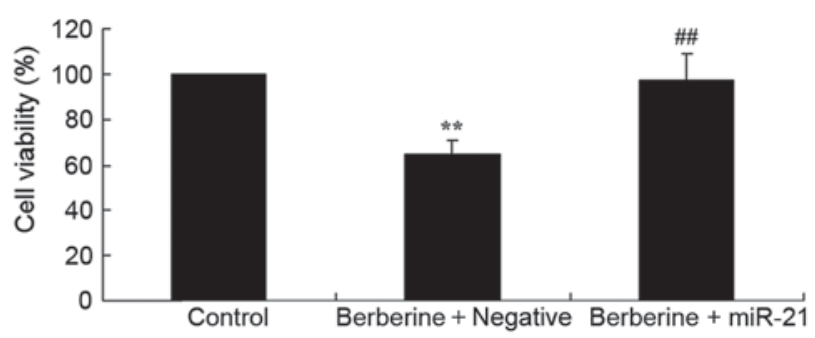

Figure 7. Effect of miR-21 overexpression on the berberine-induced reduction of HCT116 cell viability. (A) Effect of miR-21 mimics $+100 \mu \mathrm{M}$ berberine on miR-21 expression levels and (B) the $100 \mu \mathrm{M}$ berberine-induced reduction in viability of HCT116 cells. The groups are as follows: Control, control group ( $0 \mu \mathrm{M}$ Berberine); Berberine, $100 \mu \mathrm{M}$ berberine treatment group; berberine + miR-21, $100 \mu \mathrm{M}$ berberine + miR-21 mimics. ${ }^{* *} \mathrm{P}<0.01$ vs. $0 \mu \mathrm{M}$ berberine treatment group; ${ }^{\# \#} \mathrm{P}<0.01$ vs. $100 \mu \mathrm{M}$ berberine treatment group. miR, microRNA; negative, negative control mimic.

effects of berberine on apoptosis in HCT116 cells and HCT116 cells transfected with miR-21, the apoptosis rate and caspase-3 activity of HCT116 cells were measured using flow cytometry and caspase- 3 activity kit, respectively. The rate of apoptosis and caspase-3 activity were significantly decreased in HCT116 cells treated with $100 \mu \mathrm{M}$ berberine and miR-21 mimics, compared with the group treated with $100 \mu \mathrm{M}$ berberine alone (Fig. 8A and B, respectively).

Effect of miR-21 overexpression on the effect of berberine on ITG $\beta 4$ and PDCD4 protein expression levels in HCT116 cells. To investigate the association between miR-21 and the anti-cancer effects of berberine on ITG $\beta 4$ and PDCD4 protein expression in HCT116 cells, western blot analysis was performed. Overexpression of miR-21 significantly suppressed the $100 \mu \mathrm{M}$ berberine-induced increase of ITG $\beta 4$ and PDCD4 protein expression levels in HCT116 cells, compared with the group treated with $100 \mu \mathrm{M}$ berberine alone (Fig. 9).

\section{Discussion}

The morbidity rate of colon cancer is high and is increasing annually, with a clear increase being observed in developed countries and developing countries (17). Among malignant tumors of the digestive tract, colon cancer ranks the fourth in terms of mortality rates in China (17). The occurrence and progression of colon cancer involves multiple-genes (18). The present study revealed that berberine significantly suppressed cell viability, induced apoptosis and increased caspase-3 activity in human colon cancer HCT116 cells. Previous studies have demonstrated that berberine inhibits cell proliferation, induces apoptosis and inhibits the invasion of human skin squamous cell carcinoma A431 cells (19), human ovarian cancer cells (20) and CRC cells (21).

miRNAs are non-coding molecules which are expressed in breast, lung, gastric, prostate, liver, colon and pancreatic cancer, spongioblastoma, pancreatic neuroendocrine tumor 
A

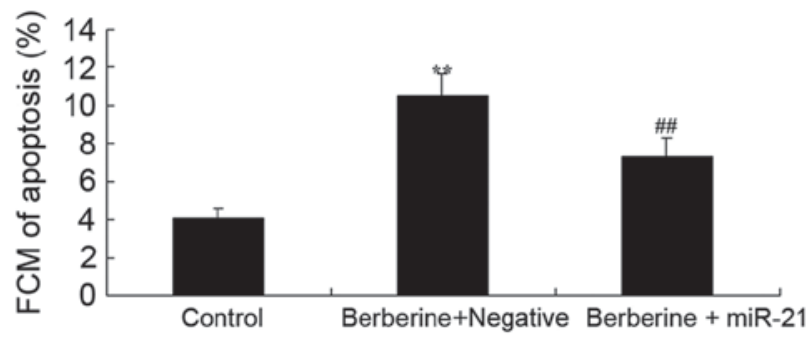

B

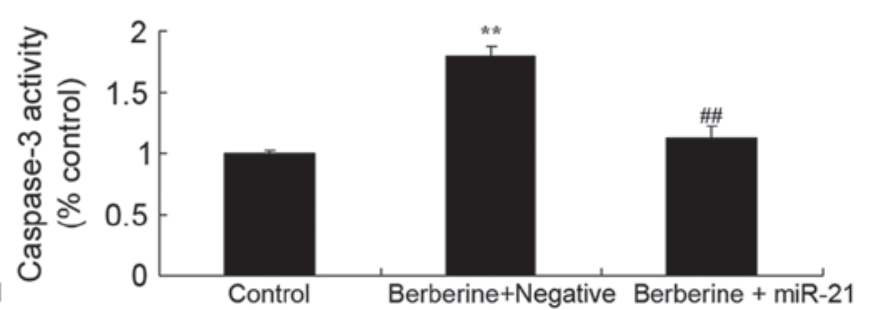

Figure 8. Effect of miR-21 overexpression on the berberine-induced increase in apoptosis and caspase-3 activity in HCT116 cells. Measurements of (A) apoptosis levels and (B) caspase-3 activity in HCT116 cells. The groups are as follows: Control, control group (0 $\mu \mathrm{M}$ Berberine); Berberine, $100 \mu \mathrm{M}$ berberine treatment group; berberine + miR-21, $100 \mu \mathrm{M}$ berberine + miR-21 mimics. ${ }^{* *} \mathrm{P}<0.01$ vs. $0 \mu \mathrm{M}$ berberine treatment group; ${ }^{\# \#} \mathrm{P}<0.01$ vs. $100 \mu \mathrm{M}$ berberine treatment group. miR, microRNA; FCM, flow cytometry; negative, negative conrol mimic.
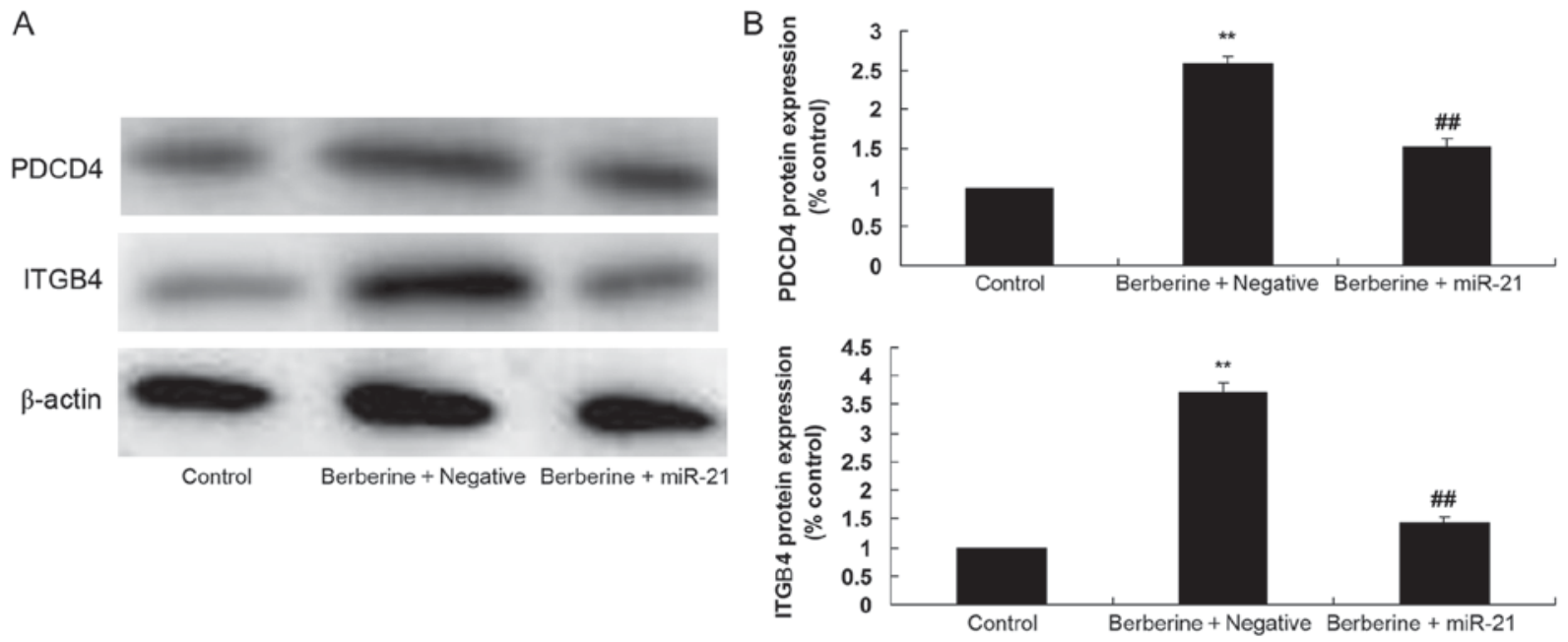

Figure 9. Effect of miR-21 overexpression on berberine-induced alterations to ITG $\beta 4$ and PDCD4 protein expression levels in HCT116 cells. (A) Western blot analysis and (B) quantification of PDCD4 protein expression levels in HCT116 cells. The groups are as follows: Control, control group; Berberine, $100 \mu \mathrm{M}$ berberine treatment group; berberine + miR-21, $100 \mu \mathrm{M}$ berberine + miR-21 mimics. ${ }^{* *} \mathrm{P}<0.01$ vs. $0 \mu \mathrm{M}$ berberine treatment group; ${ }^{\# \#} \mathrm{P}<0.01 \mathrm{vs}$. $100 \mu \mathrm{M}$ berberine treatment group. Negative, negative control mimic.

and cancer of the biliary duct (22). Since miRNAs frequently occur on complementary fragments, it is assumed that miRNAs have a relatively close association with the occurrence and progression of various types of cancer (8). It has previously been demonstrated that miR-21 has clinical and practical values for the diagnosis, treatment, assessment and prognosis of cancers (23).

miR-21 is involved in the processes of cell proliferation, invasion, blood vessel invasion and metastasis of multiple types of cancer (24). It has been demonstrated that miR-21 is associated with the sensitivity of anti-cancer drugs in vitro (24). Multiple signal pathways and regulatory factors are involved in influencing the sensitivity of anti-cancer drugs (25). Thus, miR-21 is deemed to be a potential therapeutic target. Antisense oligodeoxynucleotides combine with mature and carcinogenic miRNAs to inhibit tumor growth (26). miR-21 inhibitors increase the sensitivity of tumor cells to chemotherapeutic agents (25). Following treatment with berberine, miR-21 expression was significantly inhibited in human colon cancer HCT116 cells. In addition, overexpression of miR-21 significantly inhibited the anti-cancer effect of berberine on viability, apoptosis and caspase-3 activity in HCT116 cells. $\mathrm{Hu}$ et al (27) previously reported that berberine inhibited
$\mathrm{NF}-\kappa \mathrm{B}$ and lead to a decrease in the levels of miR-21 and B cell lymphoma 2 .

Integrin is a heterodimer molecule formed from two subunits, $\alpha$ and $\beta$ (28). In total, $20 \alpha$ and $\beta$ types have been identified, which combine into various forms. The subunits of $\alpha$ and $\beta$ are comprised of an extracellular region and a transmembrane domain, and the intracellular region ITG $\beta 4$ determines the specificity to physiological and pathological processes, including the inflammatory response, the immune response, proliferation, differentiation, vascularization, fertilization, embryo implantation and growth (29). The present study observed that berberine induced ITG $\beta 4$ protein expression in HCT116 cells.

There have been few previous studies investigating miR-21 in colon cancer. Studies have identified that increased expression of miR-21 downregulated expression levels of PDCD4, which is a cancer suppressor gene $(5,9)$. PDCD4 and miR-21 have been demonstrated to be associated with gastric carcinoma, colon and breast cancer (30). The results of the present study demonstrated that berberine induced PDCD4 protein expression in HCT116 cells. Overexpression of miR-21 was observed to significantly inhibit the anti-cancer effect of berberine on ITG $34 /$ PDCD4 protein expression levels in HCT116 cells. 
In conclusion, the present data provided evidence that berberine significantly suppressed cell viability, induced apoptosis and increased caspase-3 activity in human colon cancer HCT116 cells. The present study also demonstrated an association between miR-21 and the anti-cancer effect of berberine on the viability of colon cancer cells, which may be regulated by the miR-21-ITG $\beta 4$-PDCD4 signaling pathway. This is supported by the results of Liu et al (31), who also previously suggested that berberine sensitizes cisplatin-induced ovarian cancer cells through the miR-21/PDCD4 axis. The present study may contribute to the development of berberine for the treatment and prevention of human colon cancer.

\section{Acknowledgements}

The present study was supported by the Natural Sciences Foundation of Shandong (grant no. ZR2011HQ049) and the Jinan Youth Science and Technology Star Plan (grant nos. 20100405 and 20090208).

\section{References}

1. Holt PR, Kozuch P and Mewar S: Colon cancer and the elderly: From screening to treatment in management of GI disease in the elderly. Best Pract Res Clin Gastroenterol 23: 889-907, 2009.

2. Radhakrishnan EK, Bava SV, Narayanan SS, Nath LR, Thulasidasan AK, Soniya EV and Anto RJ: [6]-Gingerol induces caspase-dependent apoptosis and prevents PMA-induced proliferation in colon cancer cells by inhibiting MAPK/AP-1 signaling. PLoS One 9: e104401, 2014.

3. Zhu W and Xu B: MicroRNA-21 identified as predictor of cancer outcome: A meta-analysis. PLoS One 9: e103373, 2014.

4. Ribas J and Lupold SE: The transcriptional regulation of miR-21, its multiple transcripts, and their implication in prostate cancer Cell Cycle 9: 923-929, 2010.

5. Young MR, Santhanam AN, Yoshikawa N and Colburn NH: Have tumor suppressor PDCD4 and its counteragent oncogenic miR-21 gone rogue? Mol Interv 10: 76-79, 2010.

6. Wang J, Du Y, Liu X, Cho WC and Yang Y: MicroRNAs as regulator of signaling networks in metastatic colon cancer. Biomed Res Int 2015: 823620, 2015.

7. Hollis M, Nair K, Vyas A, Chaturvedi LS, Gambhir S and Vyas D: MicroRNAs potential utility in colon cancer: Early detection, prognosis, and chemosensitivity. World J Gastroenterol 21: 8284-8292, 2015.

8. Melo SA and Esteller M: Dysregulation of microRNAs in cancer: Playing with fire. FEBS Lett 585: 2087-2099, 2011.

9. Qiu X, Dong S, Qiao F, Lu S, Song Y, Lao Y, Li Y, Zeng T, Hu J, Zhang L, et al: HBx-mediated miR-21 upregulation represses tumor-suppressor function of PDCD4 in hepatocellular carcinoma. Oncogene 32: 3296-3305, 2013.

10. Mercado-Pimentel ME, Onyeagucha BC, Li Q, Pimentel AC, Jandova $J$ and Nelson MA: The S100P/RAGE signaling pathway regulates expression of microRNA-21 in colon cancer cells. FEBS Lett 589: 2388-2393, 2015.

11. Shi G, Shao J, Wang T, Wu D and Wang C: Mechanism of berberine-mediated fluconazole-susceptibility enhancement in clinical fluconazole-resistant Candida tropicalis isolates. Biomed Pharmacother 93: 709-712, 2017.

12. Daniel B, Konrad B, Toplak M, Lahham M, Messenlehner J, Winkler A and Macheroux P: The family of berberine bridge enzyme-like enzymes: A treasure-trove of oxidative reactions Arch Biochem Biophys 632: 88-103, 2017.
13. Li M, Zhang M, Zhang ZL, Liu N, Han XY, Liu QC, Deng WJ and Liao CX: Induction of apoptosis by berberine in hepatocellular carcinoma HepG2 cells via downregulation of $\mathrm{NF}-\kappa \mathrm{B}$. Oncol Res 25: 233-239, 2017

14. Li X, Zhang A, Sun H, Liu Z, Zhang T, Qiu S, Liu L and Wang X: Metabolic characterization and pathway analysis of berberine protects against prostate cancer. Oncotarget 8: 65022-65041, 2017.

15. Zhu Y, Ma N, Li HX, Tian L, Ba YF and Hao B: Berberine induces apoptosis and DNA damage in MG63 human osteosarcoma cells. Mol Med Rep 10: 1734-1738, 2014.

16. Livak KJ and Schmittgen TD: Analysis of relative gene expression data using real-time quantitative PCR and the 2(-Delta Delta C(T)) method. Methods 25: 402-408, 2001.

17. He SY, Jiang RF, Jiang J, Xiang YS and Wang L: Investigation of methylation and protein expression of the Runx3 gene in colon carcinogenesis. Biomed Rep 3: 687-690, 2015.

18. Lee LD, Mafura B, Lauscher JC, Seeliger H, Kreis ME and Gröne J: Antiproliferative and apoptotic effects of telmisartan in human colon cancer cells. Oncol Lett 8: 2681-2686, 2014.

19. Li DX, Zhang J, Zhang Y, Zhao PW and Yang LM: Inhibitory effect of berberine on human skin squamous cell carcinoma A431 cells. Genet Mol Res 14: 10553-10568, 2015.

20. Chen Q, Qin R, Fang Y and Li H: Berberine sensitizes human ovarian cancer cells to cisplatin through miR-93/PTEN/Akt signaling pathway. Cell Physiol Biochem 36: 956-965, 2015.

21. Liu X, Ji Q, Ye N, Sui H, Zhou L, Zhu H, Fan Z, Cai J and Li Q: Berberine inhibits invasion and metastasis of colorectal cancer cells via COX-2/PGE2 mediated JAK2/STAT3 signaling pathway. PLoS One 10: e0123478, 2015.

22. Reid G: MicroRNAs in mesothelioma: From tumour suppressors and biomarkers to therapeutic targets. J Thorac Dis 7: 1031-1040, 2015.

23. Pink RC, Samuel P, Massa D, Caley DP, Brooks SA and Carter DR: The passenger strand, miR-21-3p, plays a role in mediating cisplatin resistance in ovarian cancer cells. Gynecol Oncol 137: 143-151, 2015

24. Wang W, Li J, Zhu W, Gao C, Jiang R, Li W, Hu Q and Zhang B: MicroRNA-21 and the clinical outcomes of various carcinomas: A systematic review and meta-analysis. BMC Cancer 14: 819, 2014.

25. Xu G, Zhang Y, Wei J, Jia W, Ge Z, Zhang Z and Liu X: MicroRNA-21 promotes hepatocellular carcinoma HepG2 cell proliferation through repression of mitogen-activated protein kinase-kinase 3. BMC Cancer 13: 469, 2013.

26. He C, Dong X, Zhai B, Jiang X, Dong D, Li B, Jiang H, Xu S and Sun X: MiR-21 mediates sorafenib resistance of hepatocellular carcinoma cells by inhibiting autophagy via the PTEN/Akt pathway. Oncotarget 6: 28867-28881, 2015.

27. Hu HY, Li KP, Wang XJ, Liu Y, Lu ZG, Dong RH, Guo HB and Zhang MX: Set9, NF- $\kappa$ B, and microRNA-21 mediate berberine-induced apoptosis of human multiple myeloma cells. Acta Pharmacol Sin 34: 157-166, 2013.

28. Lo AK, Yuen PW, Liu Y, Wang XH, Cheung AL, Wong YC and Tsao SW: Downregulation of hemidesmosomal proteins in nasopharyngeal carcinoma cells. Cancer Lett 163: 117-123, 2001.

29. Ferraro A, Kontos CK, Boni T, Bantounas I, Siakouli D, Kosmidou V, Vlassi M, Spyridakis Y, Tsipras I, Zografos G and Pintzas A: Epigenetic regulation of miR-21 in colorectal cancer: ITG $\beta 4$ as a novel miR-21 target and a three-gene network (miR-21-ITG $34-P D C D 4)$ as predictor of metastatic tumor potential. Epigenetics 9: 129-141, 2014.

30. Wang Y, Gao X, Wei F, Zhang X, Yu J, Zhao H, Sun Q, Yan F, Yan C, Li H and Ren X: Diagnostic and prognostic value of circulating miR-21 for cancer: A systematic review and meta-analysis. Gene 533: 389-397, 2014.

31. Liu S, Fang Y, Shen H, Xu W and Li H: Berberine sensitizes ovarian cancer cells to cisplatin through miR-21/PDCD4 axis. Acta Biochim Biophys Sin (Shanghai) 45: 756-762, 2013. 